\title{
Mapping of the Distribution of Aquifier in Kawatuna Sub-district, Mantikulore District, Palu
}

\author{
Muhammad Rusydi ${ }^{1, ~ *, ~ M o h a m m a d ~ D a h l a n ~ T a h i r ~ M u s a ~}{ }^{1}, \operatorname{Badaruddin}^{1}$, Yandry Albert Momor ${ }^{1}$, \\ Sandra Sandra ${ }^{1}$, Mauludin Kurniawan ${ }^{1}$, Sitti Rugaya ${ }^{1}$, Rustan Efendi ${ }^{1}$, Rahmawati ${ }^{2}$, \\ Syaiful Hendra ${ }^{3}$, Hajra Rasmita Ngemba ${ }^{3}$ \\ ${ }^{1}$ Department of Physics, Tadulako University, Palu, Indonesia \\ ${ }^{2}$ Department of Geography Education, Tadulako University, Palu, Indonesia \\ ${ }^{3}$ Department of Information Technology, Tadulako University, Palu, Indonesia
}

Email address:

rusydiutd@untad.ac.id (M. Rusydi)

${ }^{*}$ Corresponding author

\section{To cite this article:}

Muhammad Rusydi, Mohammad Dahlan Tahir Musa, Badaruddin, Yandry Albert Momor, Sandra Sandra, Mauludin Kurniawan, Sitti Rugaya, Rustan Efendi, Rahmawati, Syaiful Hendra, Hajra Rasmita Ngemba. Mapping of the Distribution of Aquifier in Kawatuna Subdistrict, Mantikulore District, Palu. American Journal of Water Science and Engineering. Vol. 5, No. 3, 2019, pp. 105-110. doi: 10.11648/j.ajwse.20190503.11

Received: July 27, 2019; Accepted: August 24, 2019; Published: September 16, 2019

\begin{abstract}
Background: The condition of the land in Kawatuna Sub-district is dry, with vegetation overgrown only with shrubs. Dry land condition makes people difficult to get clean water sources for their daily needs. Purpose: This research aims to find out the existence of an aquifer and the depth of the aquifer in Kawatuna Sub-district. Method: The method used in this research is Vertical Electrikal Soundin (VES) with Sclumberger Configuration. The measurement is conducted on 10 measuring points. Data is processed using IP2WIN. Result: The result shown by the program is in the form of distribution of resistivity $(\rho)$, thickness $(h)$, and depth $(d)$ of each subsurface layer. Aquifer layer is shown by the resistivity value of $32.15 \Omega \mathrm{m}-48.03 \Omega \mathrm{m}$ and formation factor value of 2-5. This layer consists of sands, pebbles, and sandstones. The upper limit of this later is in the depth of $50.05-72.75 \mathrm{~m}$, while the lower limit is undetectable. Conclusion: Aquifer layer is distributed to the east and to the west. It can be seen from the depth of aquifer in the west which tends to be shallower than that in the east. Commonly, this layer is located below the impermeable clay layer.
\end{abstract}

Keywords: Aquifer, Geo-Electric Resistivity, Sclumberge Configuration, Vertical Electrical Sounding (VES)

\section{Introduction}

Palu is an area with abundant potential of groundwater resources. Based on the sheet hydrogeological map of Palu, the potential of groundwater in this area is spread in the Palu Groundwater Basin (CAT). Groundwater Basin (CAT) is an area limited by hydrogeologicalboundaries, in which all hydrogeological events such as the process of filling, flowing, and releasing groundwater take place-3]. Palu Groundwater Basin (CAT) makes this area has abundant water resources [4]. However, the existence of water resources is not distributed evenly in all area in Palu. One of the areas which are till lack of water resources is Kawatuna Sub-district. Kawatuna sub-district is located to the east of
Palu City, which is included in the area in Mantikulore District. According to the Statistics Center of Palu (Palu, 2016), the area of KelurahanKawatuna is $20.67 \mathrm{~km}^{2}$ The population is 3,575 people with a density of 173 people per $\mathrm{km}^{2}$ Residential areas are spread in the north and the south, while the east and the west parts are covered with shrubs. Topography in this area consists of plains and hills. In general, the soil surface condition is dry with vegetation overgrown with shrubs. Dry land condition makes people difficult to get clean water sources for their daily needs.

Meeting the needs of clean water in this area relies only on the water management done by the Regional Water Company (PDAM) of Palu City. The water resources of the Regional Water Company (PDAM) comes from Pondo (Poboya), 
Kawatuna, and Vatutela Rivers. According to the surrounding people, the water debit supplied by PDAM is still in a small amount. This is not comparable with the water needed by local people. This situation makes people search for other alternatives to meet the need of clean water. One of the ways is to look for groundwater resources. Groundwater resources have a very important role as an alternative source of raw water to meet the various needs of water [5-9]. Based on the information from the local people, there have already been several communities who made wells to obtain groundwater. However, the effort is unsuccessful due to the condition of dry land. To find out the existence of groundwater resources in this area, it is necessary to do a research. One method that can be used to identify the subsurface layer is geo-electric resistivity method.

Geo-electric resistivity is one of the geophysical methods commonly used for exploration to study the subsurface condition by examining the characteristics of electricity in rocks beneath the earth's surface [10-19]. The work principle of geoelectric method is to flow the electric current into the earth through 2 current electrodes, and then the potential difference is measured through 2 potential electrodes, so that the resistivity value can be known.

\section{Method}

Data collection and processing methods: Measurement of geo-electric resistivity uses Vertical Electrical Sounding methodSounding [20-27]. This method can determine the variation of resistivity value of horizontal layer of rock vertically. The configuration used is Schlumberger configuration. Data on potential difference (V), current (I), pseudo-type resistance $\left(\rho_{a}\right)$ and geometric factor values of the measurement results are inversed by the IP $2 W I N$ program and Progress. The results obtained from the program are the resistivity values $(\rho)$, depth (d), and thickness (h) of the layer at each guessing point.

To ease the process of interpretation, the electrical conductivity parameters (DHL) of well water at the research location is measured using x-plore $G L X$. The formation factor value $(\mathrm{F})$ is calculated based on water resistivity value $\left(\rho_{a}\right)$ and resistivity $\operatorname{value}(\rho)$. The result of interpretation is shown in the form of 2D cross section using CorelDraw program. Data collection in the field is carried out with the following steps:

a) Determine the position of the measurement point.

b) Determine the direction of the stretch and the electrode coordinates.

c) Install electrodes with $10 \mathrm{~m}$ space

d) Arrange the georesistivitimeter and make measurements.

e) Inject current into the ground via a current electrode.

f) Data obtained from measurements in the field are current data (I) and potential difference (V), as well as the electrode distance.

g) To avoid measurement data errors, the measurement is repeated 3 times.

Data processing and interpretation are carried out with the following steps:

a) Input field data into MS Excel Software. b) Calculate the geometry factor (K) from the measurement results using Equation (1).

$$
\rho_{w}=\frac{1000}{D H L}
$$

c) Calculate pseudo type change value ( $\rho$ a) from the measurement results using Equation (2).

$$
\rho_{t}=\rho_{b} S_{w}^{-m}=a \rho_{w} \emptyset^{-m} S_{w}^{-m}
$$

where $\rho$ is a resistivity, $\rho_{\mathrm{w}}$ is a type of bottleneck filler, $a$ is a constant that characterizes a type, rock character (texture, shape, etc.), $m$ is a constant that characterizes a cementation character, $\varnothing$ is a porosity of a rock, $\rho$ is an obstacle to a type of rock unsaturated by water, $\rho_{t_{-}}$is rock type resistance when saturated with water, $S_{w}$ is the fraction of pores containing water (saturation) and $n$ is the factor of water saturation

d) Transferring the calculated data from the MS Excel Software into Notepad Software.

e) The results of the type and elevation calculations obtained are then converted using the EarthImager2DSoftware to obtain a 2D cross-section model of subsurface resistivity distribution.

f) The results obtained from the inversion program consist of variations in pseudo-type boundary values, depth and thickness of the layers of each stretch which are then analyzed and interpreted.

g) Determine the distribution of the aquifer layer based on the cross-sectional model obtained by interpreting the processing data to obtain the level of depth and the value of a real type of hierarchy from the study area, which is then interpreted under subsurface conditions.

To get the results of a more accurate interpretation, it is necessary to support data related to the research needs that are supported, geological maps, maps of the earth, and water samples obtained from springs or well water (DHL).

\section{Result and Discussion}

DHL measurement obtains the average value of water resistivity of pore filler $\left(\rho_{\omega}\right)$, which is $15.05 \Omega \mathrm{m}$. This $\rho_{\omega}$ value and resistivity value $(\rho)$ of each layer are converted to formation factor value. Based on the resistivity value and formation factor, 3 layers are obtained, namely at layer 1, the resistivity value is $<30.1 \Omega \mathrm{m}$ indicated by brown color; at layer 2 , the resistivity value is $30.1-75.25 \Omega \mathrm{m}$ and the formation factor value is 2-5 with yellow color; and at layer 3 , the resistivity value is $>75.25$ and the formation factor value $(\mathrm{F})$ is $>5$ indicated in purple.

To interpret aquifer layer in the research location, each point of measurement is correlated in some resistivity cross section.

The resistivity cross section A-B (Figure 1) results in a correlation of 5 measuring points. This cross section extends from the north (point A4) to the south (point A8) with a minimum height of $123 \mathrm{mmsl}$ (point A3) and a maximum of $172 \mathrm{mmsl}$ (point A4). Based on the visualization of the cross section, there are 4 layers on point $A 4$, point $A 10$, and point 
A3. Meanwhile, there are 6 layers at point A2 and point A8. In this cross section, there is aquifer layer visualized in yellow color. It is assumed that this layer consists of sands, pebbles, and permeable sandstones. The upper limit of the layer is at a depth of $56.56-68.8 \mathrm{~m}$ while the lower limit is not detected. The shape of the layer follows the surface contour and tends to go deeper into the south. It is indicated by the southernmost measuring point (point A8) of which aquifer layer is at $68.8 \mathrm{~m}$. Around the cross section, there is a well that people create (Well 1), which is $200 \mathrm{~m}$ from the west of Point A3. The depth of this well is $\pm 60 \mathrm{~m}$ with clear and nosmell water. The water source of this well is allegedly in this layer. The layer is located below the impermeable clay later. Resistivity Cross Section A-B

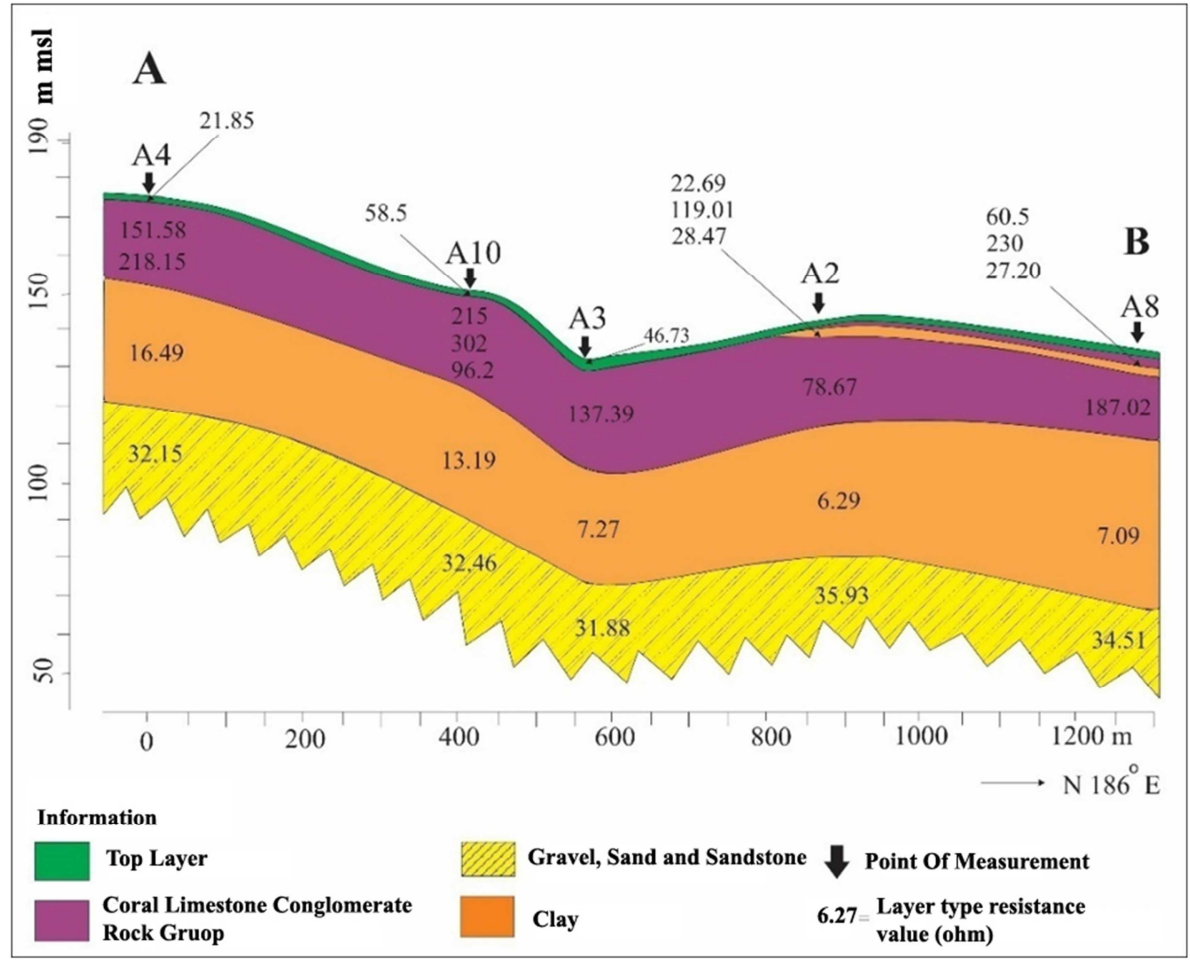

Figure 1. Resistivity Cross Section A-B.

Resistivity Cross Section C-D

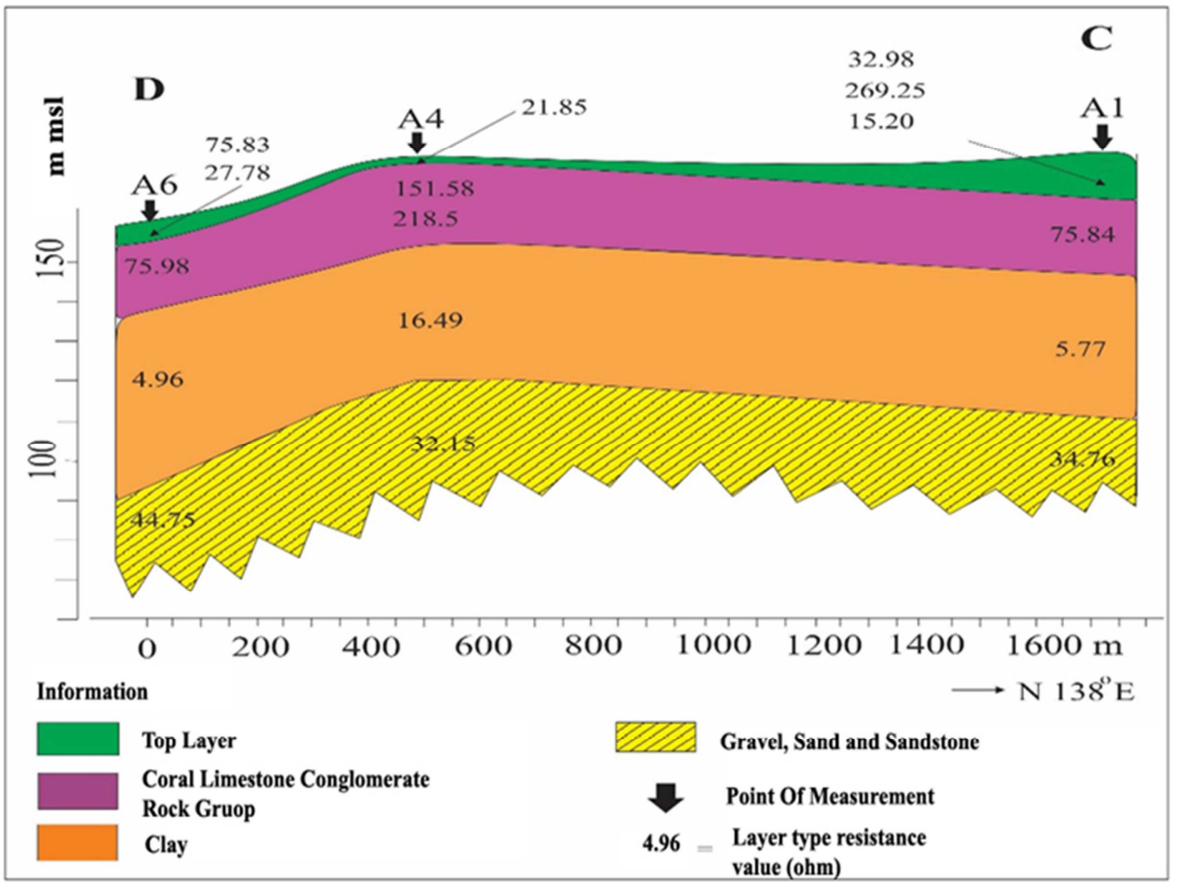

Figure 2. Resistivity Cross Section C-D. 
Based on Figure 2, the resistivity cross section C-D is a result of correlation of 3 measuring points. The length of the cross section is $\pm 1.750 \mathrm{~m}$ with topography at the altitude of $156 \mathrm{mmsl}$ (point A6) and rises to the south to an altitude of $172 \mathrm{mmsl}$ (point A4). Based on the cross section, 4 subsurface layers are obtained. The layer allegedly to be an aquifer layer (yellow) is spread evenly at each measuring point consisting of sand, pebbles, and permeable sandstone. The upper limit of this layer is at a depth of 56.56-67.9m while the lower limit is not detected. This layer is below the impermeable clay layer. Around the cross section, there is Kawatuna River which is $200 \mathrm{~m}$ from the north of point A6, and this river flows from the east to the west.

Resistivity Cross Section C-E

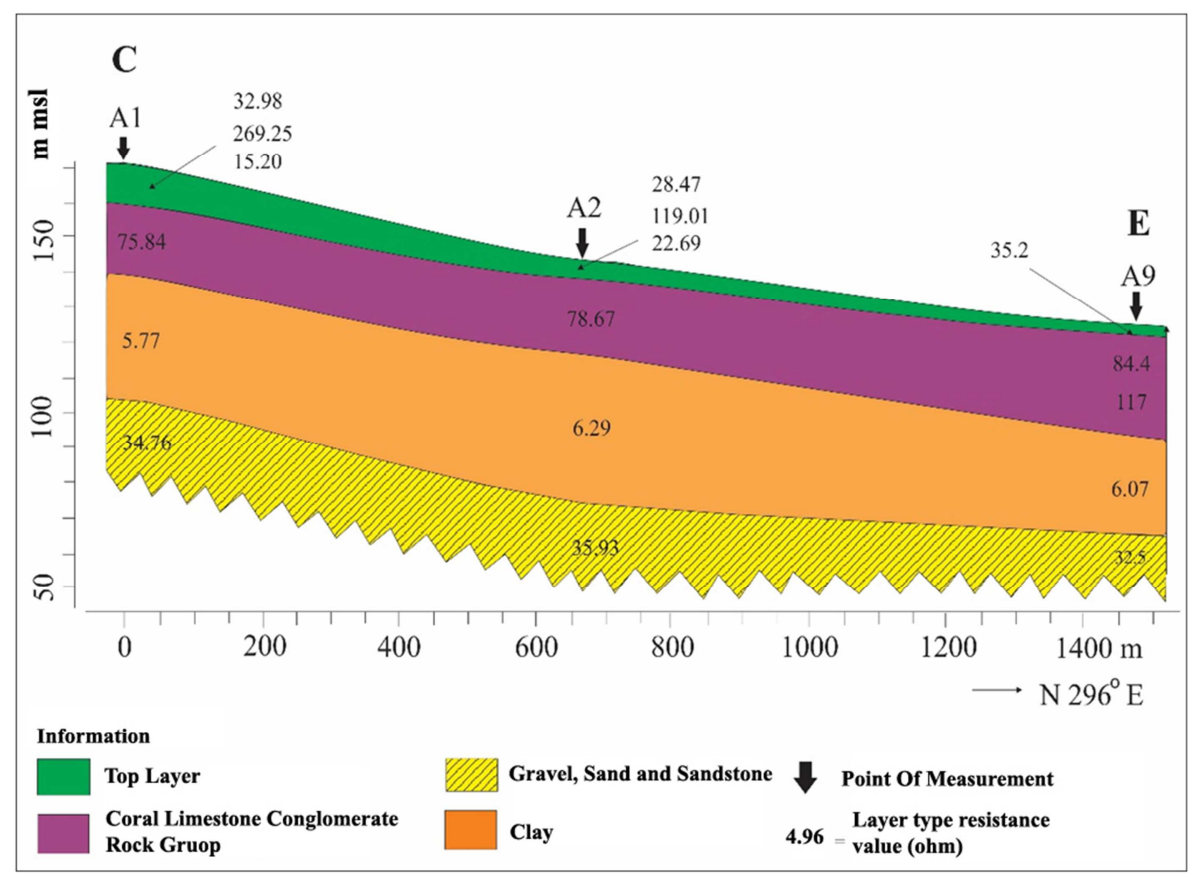

Figure 3. Resistivity Cross Section C-E.

Resistivity Cross Section C-E (Figure 3 ) is on the south of the research location. This cross section extends from the east (Point A1) to the west (Point A9) with topography at an altitude of $123 \mathrm{~m}$ above sea level (Point A9) rising to the east to an altitude of $172 \mathrm{~m}$ above sea level (Point A1). Based on the visualization of the cross section, there are 4 subsurface layers. Aquifer layer is visualized in yellow color, and allegedly consists of sands, pebbles, and permeable sandstones. The upper limit of this layer is at a depth of 55.4$63.19 \mathrm{~m}$ (Figure 4) while the lower limit is not detected. This layer is below the impermeable clay layer. Around the cross section location, there is no well created by people.

Resistivity Cross Section D-E

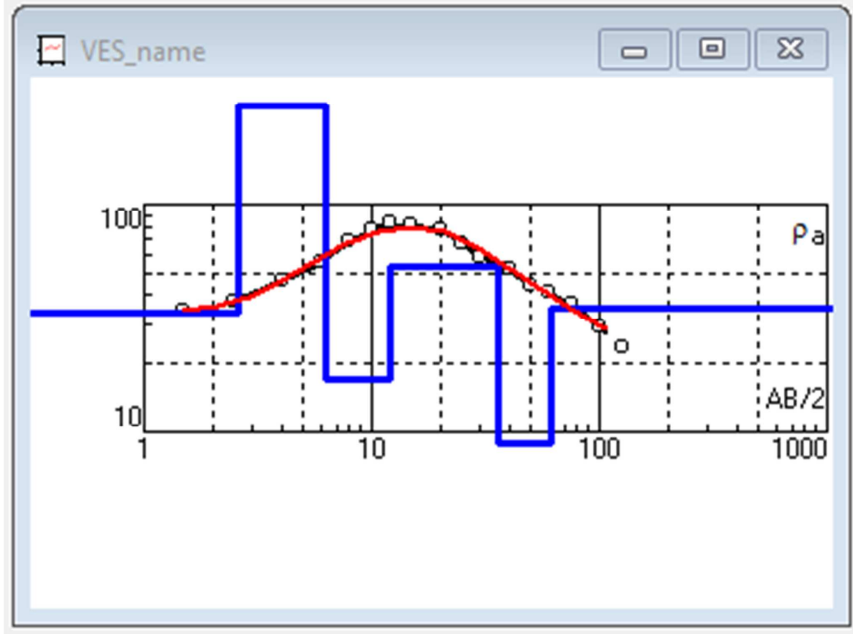

\begin{tabular}{|c|c|c|c|c|}
\hline \multicolumn{3}{|c|}{ Uf Error $=3.11 \%$} & \multicolumn{2}{|c|}{\begin{tabular}{|l|l} 
& 0 \\
\end{tabular}} \\
\hline $\mathbf{N}$ & $\rho$ & h & d & Alt \\
\hline 1 & 33.3 & 2.6 & 2.6 & -2.6 \\
\hline 2 & 269 & 3.7 & 6.3 & -6.3 \\
\hline 3 & 17.1 & 5.71 & 12 & -12.01 \\
\hline 4 & 53.6 & 24 & 36 & -36.01 \\
\hline 5 & 8.98 & 25 & 61 & -61.01 \\
\hline 6 & 35.2 & & & \\
\hline & & & & \\
\hline & & & & \\
\hline & & & & \\
\hline & & & & \\
\hline
\end{tabular}

Figure 4. VES data processing point A1. 
Resistivity Cross Section D-E

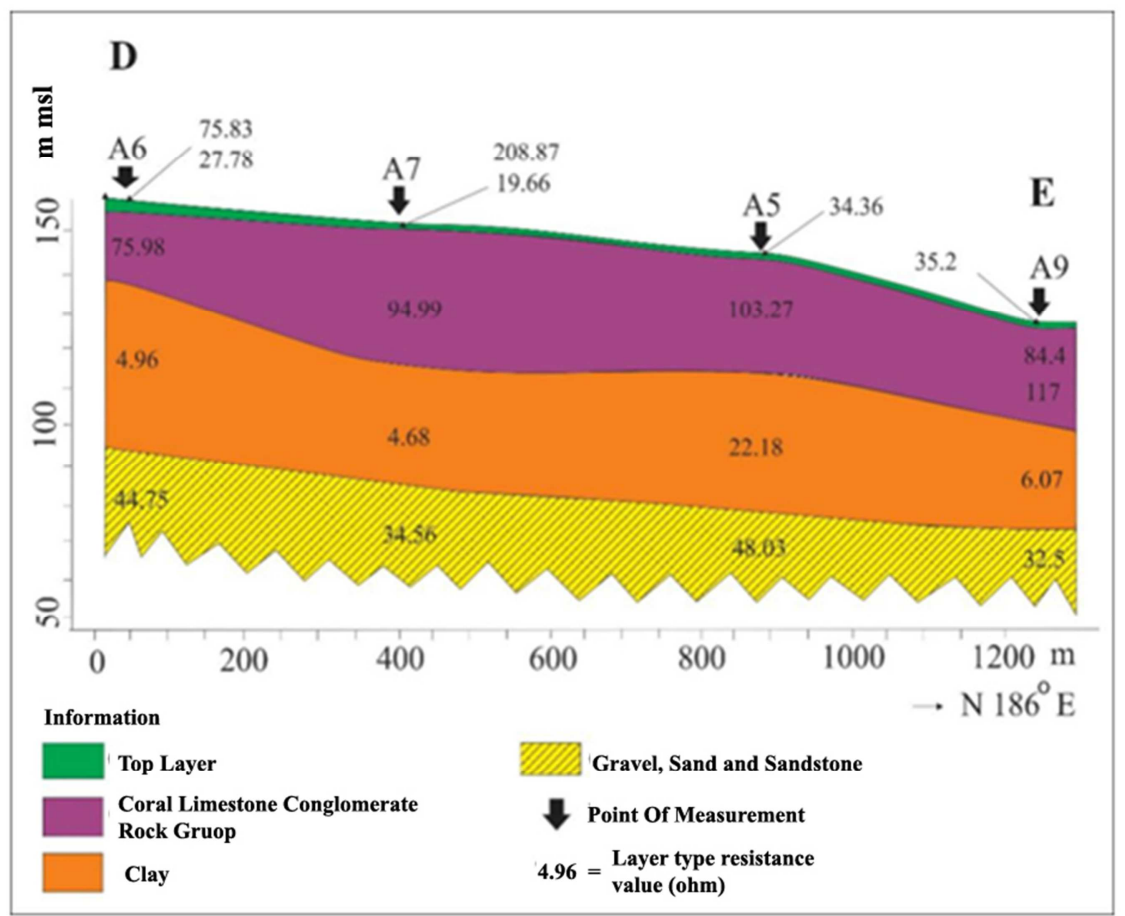

Figure 5. Resistivity Cross Section D-E.

Cross section on Figure 5 consists of Point A6, Point A7, Point A5 and Point A9. This cross section extends from the north (Point A6) to the south (Point A9) with a minimum altitude of $123 \mathrm{~m}$ above sea level (Point A9) and a maximum of $156 \mathrm{~m}$ above sea level (Point A6). Based on the visualization of the cross section, 5 layers are arranged at Point A6. At Point A7, Point A5, and Point A9, 4 layers are obtained. Based on the cross section, there is aquifer layer visualized on yellow color that allegedly consists of sands, pebbles, and permeable sandstones. The upper limit of this layer is at a depth of 55.4-72.76mwhile the lower limit is not detected. The shape of this layer follows the surface contours and tends to be shallower to the west. It is indicated by the westernmost point of the cross section (Point A9) of which aquifer layer is at a depth of $50.06 \mathrm{~m}$. Around the cross section location, there is no well created by people. Around the cross-sectional location, there is a well belonging to the River Basin Hall (BWS) of Sulawesi II (Well 2) which is $300 \mathrm{~m}$ from Point A5. The depth of this well is \pm 105 mwith clear and nosmell water. The water source allegedly comes from this layer. The layer is located under the impermeable clay layer.

Based on the result of interpretation of all cross section, the detected aquifer layers have resistivity value of 32.15$48.03 \Omega \mathrm{m}$ and allegedly consist of sands, pebbles, and permeable sandstones. The pattern of aquifer distribution tends to be shallow to the west that that in the east. It can be seen in the westernmost point of measurement (Point A9) of which is the depth of the aquifer is at a depth of $55.4 \mathrm{~m}$. Meanwhile, the aquifer at the measuring point to the east (Point A1) is at a depth of $61 \mathrm{~m}$. The depth of the aquifer found is in accordance with the depth of the well around the research location, where there is a well that people create (W 1) with a depth of 60 mand a well belonging to Sulawesi BWS III (Well 2) with a depth of $105 \mathrm{~m}$, and it is assumed that the well water is in this layer. Generally, this layer is located at below the impermeable clay layer.

\section{Conclusion and Recommendations}

Based on the result and purpose of the research, it can be concluded that the position of aquifer layer in Kawatuna Subdistrict is detected at a depth of $55.4-72.75 \mathrm{~m}$. This layer is interpreted by the resistivity values of $31.9-48 \Omega m$ with formation factor value of $2-5$. It is assumed that the layer consists of sands, pebbles, and permeable sandstones. This layer is distributed evenly to the east and to the west. It can be seen that the aquifer depth in the west tends to be shallower than that in the east. Generally, this layer is located below the impermeable clay layer.

\section{Acknowledgements}

The authors would like to thank the Tadulako University forthe research funding.

\section{Statement on Conflicts of Interest}

The authors declare that they have no competing interests. 


\section{Author Contribution}

Muhammad Rusydi (conception and design of the study, preparation of draft manuscript, doing revisions or providing critique); Mohammad Dahlan Tahir Musa(data analysis and interpretation); Badaruddin (data analysis and interpretation); Yandry Albert Momor (sectional scientific management); Sandra Sandra(sectional scientific management);Mauluddin Kurniawan (sectional scientific management), Sitti Rugaya (sectional scientific management); Rustan Efendi (data analysis and interpretation); Rahmawati (data analysis and interpretation); Syaiful Hendra (data analysis and interpretation);Hajra Rasmita Ngemba (data analysis and interpretation).

\section{References}

[1] J. G. Arnold, P. M. Allen, and G. Bernhardt, "A comprehensive surface-groundwater flow model," J. Hydrol., 1993.

[2] E. Kalbus, F. Reinstorf, and M. Schirmer, "Measuring methods for groundwater-Surface water interactions: A review," Hydrology and Earth System Sciences. 2006.

[3] M. Rodell, J. Chen, H. Kato, J. S. Famiglietti, J. Nigro, and C. R. Wilson, "Estimating groundwater storage changes in the Mississippi River basin (USA) using GRACE," Hydrogeol. J., 2007.

[4] T. A. dan A. A. Zeffitni, "Studipelayanan air minumdalamrangkamencapai target mdgs di kotapalu," Semin. Nas. Tek. Sipil V Tahun 2015-UMS, 2015.

[5] L. Roberts, Y. Chartier, O. Chartier, G. Malenga, M. Toole, and H. Rodka, "Keeping clean water clean in a Malawi refugee camp: A randomized intervention trial," Bull. World Health Organ., 2001.

[6] J. Horsfield, Water Sustainable World. 2018.

[7] UN WWAP (United Nations World Water Assessment Programme), "World water quality facts and statistics," Clean Ater a Heal. World, 2008.

[8] United Nations, "Clean Water and Sanitation: Why It Matters," Sustain. Dev. Goals Briefs, 2016.

[9] T. Thompson, M. Sobsey, and J. Bartram, "Providing clean water, keeping water clean: An integrated approach," in International Journal of Environmental Health Research, 2003.

[10] T. H. Abdel Hafeez, H. S. Sabet, A. N. El-Sayed, and M. A. Zayed, "Geoelectrical exploration of groundwater at West Dayrout Area, Assiut Governorate, Egypt," NRIAG J. Astron. Geophys., vol. 7, no. 2, pp. 279-296, 2018.

[11] A. M. S. Abd El-Gawad, A. S. Helaly, and M. S. E. Abd ElLatif, "Application of geoelectrical measurements for detecting the ground-water seepage in clay quarry at Helwan, southeastern Cairo, Egypt," NRIAG J. Astron. Geophys., vol. 7, no. 2, pp. 377-389, 2018.

[12] D. Darsono, "Identifikasi Akuifer Dangkal dan Akuifer
Dalamdengan Metode Geolistrik (Kasus: Di Kecamatan Masaran),” Indones. J. Appl. Phys., 2016.

[13] V. S. Asare and A. Menyeh, "Geo-Electrical Investigation of Groundwater Resources and Aquifer Characteristics in Some Small Communities in The Gushiegu and Karaga Districts of Northern Ghana,” Int. J. Sceince Technol. Res., 2013.

[14] P. D. C. Mbonu, J. O. Ebeniro, C. O. Ofoegbu, and A. S. Ekine, "Geoelectric sounding for the determination of aquifer characteristics in parts of the Umuahia area of Nigeria," GEOPHYSICS, 2002.

[15] K. S. Okiongbo and E. Akpofure, "Determination of Aquifer Properties and Groundwater Vulnerability Mapping Using Geoelectric Method in Yenagoa City and Its Environs in Bayelsa State, South South Nigeria,” J. Water Resour. Prot., 2012.

[16] E. Rolia and D. Sutjiningsih, "Application of geoelectric method for groundwater exploration from surface (A literature study)," in AIP Conference Proceedings, 2018.

[17] G. Akhter and M. Hasan, "Determination of aquifer parameters using geoelectrical sounding and pumping test data in Khanewal District, Pakistan,” Open Geosci., 2016.

[18] G. Halik and J. Widodo, "PendugaanPotensi Air Tanah DenganMetodeGeolistrik," Media Tek. Sipil, 2008.

[19] N. U. Ugwu, R. T. Ranganai, R. E. Simon, and G. Ogubazghi, "Geoelectric Evaluation of Groundwater Potential and Vulnerability of Overburden Aquifers at Onibu-Eja Active Open Dumpsite, Osogbo, Southwestern Nigeria," J. Water Resour. Prot., 2016.

[20] U. Hamzah, A. R. Samsudin, and E. P. Malim, "Groundwater investigation in Kuala Selangor using vertical electrical sounding (VES) surveys,” Environ. Geol., 2007.

[21] S. Niwas and M. Celik, "Equation estimation of porosity and hydraulic conductivity of Ruhrtal aquifer in Germany using near surface geophysics," J. Appl. Geophys., 2012.

[22] N. Perttu, K. Wattanasen, K. Phommasone, and S. Å. Elming, "Characterization of aquifers in the Vientiane Basin, Laos, using Magnetic Resonance Sounding and Vertical Electrical Sounding," J. Appl. Geophys., 2011.

[23] E. Faleiro, G. Asensio, and J. Moreno, "Improved measurements of the apparent resistivity for small depths in Vertical Electrical Soundings," J. Appl. Geophys., 2016.

[24] V. N. Pham, D. Boyer, J.-L. Le Mouël, and T. Kim Thoa Nguyen, "Hydrogeological investigation in the Mekong Delta around Ho-Chi-Minh City (South Vietnam) by electric tomography," ComptesRendusGeosci., 2002.

[25] I. Akca, T. Günther, M. Müller-Petke, A. T. Başokur, and U. Yaramanci, "Joint parameter estimation from magnetic resonance and vertical electric soundings using a multiobjective genetic algorithm," Geophys. Prospect., 2014.

[26] F. Ozcep, O. Tezel, and M. Asci, "Correlation between electrical resistivity and soil-water content:Istanbul and Golcuk,” Int. J. Phys. Sci., 2010.

[27] M. A. Al-Garni et al., "Groundwater Investigation Using Combined Geophysical Methods*,” J. Appl. Geophys., 2002. 